\title{
MENGOPTIMALKAN \\ PROSES PEMBELAJARAN PAI \\ MELALUI MEDIA LINGKUNGAN
}

\author{
Irjus Indrawan \\ Dosen Manajemen Pendidikan Islam \\ Universitas Islam Indragiri (UNISI) Tembilahan Riau
}

\begin{abstract}
Abstrak
Lingkungan merupakan media dalam proses pembelajaran. Media lingkungan merupakan salah satu upaya untuk mengoptimalkan pembelajaran dan meningkatkan hasil pembelajaran. Sesuai dengan karakteristik pembelajaran yang berorientasi kepada siswa, maka proses pembelajaran bisa terjadi dimana saja dan kelas bukanlah satu-satunya tempat belajar para peserta didik. Untuk tercapainya proses dalam pembelajaran yang aktif, terpadu, dan memiliki karakter maka lingkungan tidak dapat terpisahkan dari proses pembelajaran. Karena hakikatnya adalah pembelajaran suatu interaksi antara individu dan lingkungan. Lingkungan menyediakan rangsangan (stimulus) terhadap individu dan sebaliknya individu memberikan respon terhadap lingkungan. Melalui pendekatan lingkungan ini siswa diajak memahami konsep sain dengan menggunakan lingkungan sebagai sumber belajar. Dengan demikian mereka diharapkan akan memilki kepedulian terhadap lingkungannya dan berawal dari pemahaman dan kepedulian itu mereka dapat mencari solusi, mengambil keputusan dan melakukan tindakan nyata apa bila mereka suatu ketika menghadapi masalah dalam lingkungan mereka sendiri.
\end{abstract}

Keyword: Pembelajaran PAI, Media, Lingkungan 


\section{A. Pendahuluan}

Proses pendidikan itu sesungguhnya telah berlangsung sepanjang sejarah dan berkembang sejalan dengan perkembangan sosial budaya manusia di permukaan bumi. Bila diperhatikan dalam sejarah pertumbuhan suatu masyarakat, pendidikan senantiasa menjadi perhatian utama dalam rangka memajukan generasi sejalan dengan tuntutan masyarakat. Maju mundurnya suatu bangsa tergantung maju mundurnya pendidikan. ${ }^{1}$

Mengacu pada kenyataan di atas, sesuai dengan tujuan pendidikan Nasioanal yaitu untuk berkembangnya potensi peserta didik menjadi manusia yang berakhlak mulia, sehat, berilmu, cakap, kreatif, mandiri, demokrasi dan bertanggung jawab. ${ }^{2}$ Sementara yang hendak di capai adalah terbentuknya kepribadian yang bulat dan utuh sebagai manusia individual dan sosial serta hamba Tuhan yang mengabdi diri kepada-Nya.

Berkembangnya ilmu pengetahuan terutama dalam bidang sain dan teknologi tidak hanya akan mempengaruhi pertumbuhan bidang sosial dan budaya namun dapat menciptakan kebudayaan teknologi yang selanjutnya akan menimbulkan krisis moral dalam kehidupan masyarakat. Ini dapat dilihat dari struktur kehidupan sosial yang tidak mampu lagi memberikan solusi seperti yang diharapkan untuk menjamin kelestarian sistem kehidupan itu sendiri. ${ }^{3}$

\footnotetext{
${ }^{1}$ Sudirman, Ilmu Pendidikan, (Bandung: Rosda Karya, 1991), h. 3.

${ }^{2}$ Hasbullah, Dasar-Dasar Ilmu Pendidikan, (Jakarta: Rajawali Press, 2005), h. 320.

3 Andi haris Prabawa. Paragdima Pengembangan Kurikulum Pendidikan Tinggi (Surakarta: Universitas Muhammadiyah, 2002), h. 114.
} 


\section{Irjus Indrawan}

Mengacu pada kenyataan di atas, munculah berbagai upaya untuk meninjau kembali sistem pendidikan nasional terutama pendidikan islam yang sudah tidak sesuai lagi dengan perkembangan kebutuhan hidup. Ini dikarenakan pendidikan akan terus menghadapi perubahan tuntutan manusia sesuai dengan perubahan yang terjadi di masyarakat serta perkembangan sain dan terknologi. Sehingga peran serta efektifitas pendidikan agama di sekolah sebagai pemberi nilai keagamaan terhadap kesejahteraan masyarakat dipertanyakan. ${ }^{4}$

Oleh sebab itu, maka pendidikan agama Islam di sekolah harus dilaksanakan dengan baik sehingga mampu diterima dan dilaksanakan dalam kehidupan sesuai dengan yang dicita-citakan bersama. Sedangkan fungsi pendidikan agama Islam di sekolah adalah sebagai:

1. Pengembangan keimanan dan ketaqwaan kepada Allah SWT.

2. Penanaman nilai ajaran Islam sebagai pedoman dalam mencapai kebahagian dunia akherat.

3. Menyesuaikan mental siswa terhadap lingkungan.

4. Perbaikan kesalahan, kelemahan siswa dalam keyakinan, pengamalan ajaran Islam dalam kehidupan sehari-hari.

5. Pencegahan dari hal-hal negatif budaya asing

6. Pengajaran tentang ilmu pengetahuan keagamaan, sistem dan fungsionalnya.

7. Penyatuan siswa untuk mendalami pendidikan kejenjang yang lebih baik. $^{5}$

4 Dasim Budimansyah, Model Pembelajaran PAI Berbasis Portifolio, (Bandung: PT. Ganesindo, 2003), h. 1.

${ }^{5}$ Ibid. 
Berdasarkan uraian tersebut, jika pendidikan agama Islam tersebut dilaksanakan dengan baik, maka kehidupan masyarakatpun akan menjadi baik. namun pada kenyataannya, pendidikan agama Islam kurang memberikan kontribusi yang maksimal, ini dapat ditelusuri pada kenyataan yang ada yakni pendidikan agama Islam dihadapkan pada berbagai kendala antara lain sedikitnya waktu yang tersedia sementara materi ajar sangat banyak, pendidikan agama Islam harus dikembangkan dengan menekankan kerterpaduan antara tiga lingkungan pendidikan yaitu keluarga, sekolah dan masyarakat sehingga guru PAI perlu mendorong serta memantau kegiatan pendidikan agama yang dialami siswa dilingkungannya sehingga terwujudnya keselarasan dan kesesuaian sikap dan perilaku dalam pembinaanya. Sehingga menjadi tanggung jawab sekolah untuk mewujudkan keterpaduan antara pendidikan agama di lingkungan keluarga, masyarakat dan dilaksanakan oleh guru agama melalui proses belajar mengajar sebagai pelaksanaan kurikulum di sekolah. Pendidikan agama Islam adalah bimbingan jasmani rohani berdasarkan hukum-hukum agama islam menuju kepada terbentukya kepribadian utama menurut ukuran-ukuran Islam. ${ }^{6}$

Peran pendidikan agama Islam dalam pendidikan nasional adalah untuk membina dan mendasari kehidupan siswa dengan nilai-nilai agama. Dengan tujuan agar siswa mampu mengamalkan ajaran Islam secara benar sesuai dengan ajaran Islam. Oleh karena itu, maka guru pendidikan agama Islam khususnya harus dapat meningkatkan

${ }^{6}$ Ahmad D. Marimba, Pengantar Filsafat Pendidikan Islam, (Bandung: PT. Al-Ma'arif, 2003), h. 23. 


\section{Irjus Indrawan}

keprofesionalannya dalam mendesain program pembelajaran yang baik dan sesuai dengan tuntutan kehidupan modern yang ada saat ini. Guru merupakan pendidik profesional dengan tugas utama mendidik, mengajar, membimbing, mengarahkan, melatih, menilai dan mengevaluasi peserta didik. ${ }^{7}$ Profesional berasal dari kata profession yang mengandung arti pekerjaan yang memerlukan keahlian khusus yang diperoleh dari pendidikan atau latihan khusus. Para profesional adalah para ahli didalam bidangnya yang telah memperoleh pendidikan atau pelatihan yang khusus untuk pekerjaan tersebut. ${ }^{8}$ Sedangkan secara harfiah profesionalisme adalah suatu jabatan yang mensyaratkan pengetahuan dan keterampilan khusus yang diperoleh dari pendidikan akademis yang intensif. ${ }^{9}$

Dalam meningkatkan profesionalisme sebagai seorang guru, maka guru harus mempunyai sepuluh kompetensi dasar, yaitu:

1. Penguasaan bahan pelajaran serta konsep dasar keilmuan.

2. Pengelolaan program belajar mengajar.

3. Pengelolaan kelas.

4. Penggunaan media dan sumber ajar.

5. Penguasaan landasan-landasan kependidikan.

6. Pengelolaan interaksi belajar mengajar.

7. Penilaian prestasi belajar.

8. Pengenalan fungsi dan program bimbingan dan penyuluhan.

${ }^{7}$ Rugaiyah, Atiek Sismiati. Profesi Kependidikan, (Bogor: Ghalia Indonesia, 2011), h. 8.

${ }^{8}$ M. Arifin, Kapita Selekta Pendidikan (Jakarta: Bumi Aksara, 1991), h. 105.

${ }^{9}$ Isjoni, Pengembangan Profesional Guru. (Pekanbaru: Cendikia Insani, t.t.), h. 82 . 
9. Pengenalan dan penyelenggaraan administrasi sekolah.

10. Pemahaman prinsip-prinsip dan pemanfaatan hasil-hasil penelitian untuk kepentingan mutu pengajaran. ${ }^{10}$

Selanjutnya menurut Moh User Usman dalam buku menjadi guru profesional mengatakan ada beberapa hal yang perlu diperhatikan guru dalam mendesain program pembelajaran pendidikan agama Islam, yaitu:

1. Menetapkan tujuan pembelajaran.

2. Memilih dan mengembangkan bahan pembelajaran.

3. Memilih dan mengembangkan strategi belajar mengajar.

4. Memilih dan mengembangkan media pengajaran yang sesuai.

5. Memilih dan memanfaatkan belajar. ${ }^{11}$

\section{B. Mengoptimalkan Kegiatan Pembelajaran PAI Melalui Media Lingkungan.}

Profesi sebagai seorang guru bukanlah suatu pekerjaan yang mudah. Guru mempunyai tugas untuk mendorong, membimbing dan memberikan fasilitas belajar bagi siswa untuk mencapai suatu tujuan. Guru mempunyai tanggung jawab untuk melihat segala sesuatu yang terjadi didalam kelas untuk membantu proses perkembangan siswa. ${ }^{12}$ Guru adalah pendidik profesional, karena secara implisit ia telah

${ }^{10}$ Nana Syaodhisukma Dinata, Pengembangan Kurikulum Teori dan Praktek, (Bandung: Remaja Rosda Karya, 2002), h. 193.

${ }_{11}$ Moh. User Usman, Menjadi Guru Profesional (Bandung: Rosda Karya. Bandung. 1995, hlm. 18-19

${ }^{12}$ Slameto, Belajar dan Faktor-Faktor Yang Mempengaruhinya. Rineka Cipta. Jakarta. 2003. hal. 97 


\section{Irjus Indrawan}

merelakan dirinya menerima dan memikul sebagian tanggung jawab pendidikan yang terpikul dipundak para orang tuanya. ${ }^{13}$

Oleh karena itu, untuk menjadi seorang guru yang profesional harus memilki kompetensi dasar dalam melaksanakan proses pengajaran terutama dalam mendesain strategi pembelajaran dalam hal ini adalah strategi lingkungan dalam proses pembelajaran. Lingkungan yaitu situasi sekitar dimana pesan disampaikan, lingkungan dapat berupa fisik (gedung sekolah, kampus, perpustakaan, lab, studio, museum, taman dll) maupun lingkungan non fisik (suasana belajar dan lain, lain). ${ }^{14}$

Strategi pembelajaran yang menggunakan media lingkungan dalam proses kegiatan belajar mengajar maksudnya adalah menggunakan segala apa saja yang bisa mendukung kegiatan belajar mengajar itu sendiri. Strategi pembelajaran yang menggunakan media lingkungan adalah salah satu strategi yang mendorong siswa agar belajar tidak tergantung dari apa yang ada dalam buku atau kitab yang merupakan pegangan guru. Konsep pembelajaran ini berangkat dari belajar konstektual dengan lebih mengedepankan bahwa hal yang perlu dipelajari terlebih dahulu oleh siswa adalah apa yang ada pada lingkungannya. ${ }^{15}$

${ }^{13}$ Zakiyah Daradjad, Ilmu Pendikan Islam, (Jakarta: Bumi Aksara. t.t.), 26. h. 39.

${ }^{14}$ Ahmad Rohani, Media Instruksional Edukatif, (Jakarta: Rineka Cipta, 1997), h. $108-109$.

15 Hamzah B. Uno, Nurdin Mohamad, Belajar Dengan Pendekatan Pembelajaran Aktif, Inovatif, Lingkungan, Kreatif, Efektif, Mandiri (PAILKEM). (Jakarta: Bumi Aksara, 2011), h. 11. 
Strategi pembelajaran dengan menggunakan lingkungan dalam proses pembelajaran, siswa tidak hanya untuk diajak mempelajari konsep tentang lingkungan tetapi lingkungan juga dapat menjadi salah satu sumber belajar. Hal ini senada dengan pernyataan dan penuturan dari Depdiknas yang mengatakan bahwa belajar dengan menggunakan lingkungan memungkinkan siswa menemukan hubungan yang sangat bermakna antara ide-ide abstrak dan penerapan praktis di dalam kontek dunia nyata, konsep dipahami melalui proses penemuan, pemberdayaan dan hubungan. ${ }^{16}$

Strategi lingkungan adalah segala sesuatu yang ada di luar dari diri individu. Adapun lingkungan dalam proses pengajaran merupakan segala apasaja yang bisa mendukung pengajaran itu sendiri yang dapat difungsikan sebagai sumber pengajaran atau sumber belajar. Strategi lingkungan ini, bukan hanya guru dan buku pelajaran saja yang menjadi sumber belajar tetapi banyak hal yang dapat dipelajari dan dijadikan sumber belajar peserta didik.

Lingkungan merupakan sumber peran yang sangat kaya sesuai dengan tuntutan kurikulum. Ada dua bentuk lingkungan belajar, pertama lingkungan yang sengaja didesain untuk belajar siswa seperti laborlatorium, perpustakaan, ruang internet dan lain sebagainya, kedua, lingkungan yang tidak didesain untuk proses pembelajaran akan tetapi keberadaannya dapat dimanfaatkan seperti halaman sekolah, kantin, masjid, hutan dan lain sebagainya. Lingkungan dapat dimanfaatkan oleh setiap guru karena selain memiliki informasi yang sangat kaya

16 Depdiknas, Manajemen Peningkatan Mutu Berbasis Sekolah. (Jakarta: Dirjen Dikdasmen, 1990), h. 9. 


\section{Irjus Indrawan}

untuk dijadikan materi pelajaran juga dapat secara langsung dijadikan tempat belajar siswa. ${ }^{17}$

Pengajaran yang tidak menghiraukan lingkungan akan mengakibatkan peserta didik tidak mampu beradaptasi dengan kehidupan tempat peserta didik itu hidup. Pengetahuan yang ia kuasai belum menjamin pada bagaimana ia menerapkan pengetahuannya itu bagi lingkungan yang ia hadapi.

Menurut Winaputra, ia mengatakan bahwa pemanfaatan lingkungan didasari oleh pendapat pembelajaran yang lebih bernilai, karena para siswa diharapkan dengan peristiwa dan keadaan yang seharusnya. ${ }^{18}$

Samatowa dalam bukunya bagaimana membelajarkan IPA di sekolah dasar juga mengatakan bahwa pembelajaran juga dapat dilakukan di luar kelas dengan memanfaatkan lingkungan sebagai laboratorium alam. ${ }^{19}$

Selanjutnya Iskandar di dalam bukunya pendidikan ilmu pengetahuan alam mengatakan bahwa bangkitnya motivasi belajar intrinsik siswa sangat dipengaruhi oleh motivasi ekstrinsik, yaitu behavior (lingkungan). ${ }^{20}$

\footnotetext{
${ }^{17}$ Wina Sanjaya, Perencanaan dan Desain Sistem Pembelajaran, (Jakarta: Kencana Prenada Media Group, 2011), h. 148.

${ }^{18}$ Udin Winaputra, Strategi Belajar Mengajar, (Jakarta: Universitas Terbuka, 1997), h. 49.

19 Usman Samatowa, Bagaimana Membelajarkan IPA di Sekolah Dasar. (Jakarta: PT. Pustaka Indonesia Press), h. 173.

${ }^{20}$ M Sindi Iskandar dan M Eddy Hidayat, Pendidikan Ilmu Pengetahuan Alam, (Jakarta: Depdikbud Dikti: Loan 1997), h.
} 
Berdasarkan dari definisi yang diungkapkan oleh berbagai pakar pendidikan di atas tersebut, maka dapat disimpulkan bahwa lingkungan merupakan sumber belajar yang paling efektif dan efesien serta tidak membutuhkan biaya yang besar dalam meningkatkan motivasi belajar peserta didik. Dengan mengetahui lingkungan yang ada di sekitar peserta didik maka kelak peserta didik setelah selesai dari belajar maka peserta didik akan berusaha memanfaatkan lingkungan ini sebagai sumber daya yang akan dikelolanya sebagai sumber yang dapat memberikan nilai tambah bagi peserta didik tersebut.

\section{Cara Menggunakan Lingkungan Sebagai Media Pembelajaran.}

Dalam Proses Pembelajaran, media telah dikenal sebagai alat bantu mengajar yang seharusnya dimanfaatkan oleh pengajar, namun kerap kali terabaikan. Tidak dimanfaatkannya media dalam proses pembelajaran pada umumnya dikarenakan oleh berbagai alas an seperti waktu persiapan mengajar terbatas, sulit mencari media yang tepat, biaya tidak mencukupi ataupun alasan yang lain. ${ }^{21}$ Media seperti radio, televisi, video, multi media, dan media lainnya telah digunakan dan dapat membantu meningkatkan mutu pendidikan. E-learning dapat mengacu pada semua kegiatan pelatihan yang menggunakan media elektronik atau teknologi informasi sebagai media kegiatan pendidikan. $^{22}$

${ }^{21}$ Hamzah B. Uno, Profesi Kependidikan, (Jakarta: Bumi Aksara, 2008), h. 109.

22 Empy Effendi, Hartono Zhuang. E-Learning, Konsep dan Aplikasi. (Yogyakarta: Andi, 2005), h. 4. 


\section{Irjus Indrawan}

Lingkungan merupakan sumber belajar dalam proses pembelajaran merupakan salah satu upaya untuk mengoptimalkan pembelajaran dan meningkatkan hasil pembelajaran. Sesuai dengan karakteristik pembelajaran yang berorientasi kepada siswa, maka proses pembelajaran bisa terjadi dimana saja dan kelas bukanlah satusatunya tempat belajar para peserta didik. Para peserta didik dapat memanfaatkan berbagai tempat belajar sesuai dengan kebutuhan dan sifat materi pelajaran, contohnya: para pelajar akan belajar tentang fungsi pasar maka pasar itu sendiri merupakan tempat belajar siswa. ${ }^{23}$

Dalam mengoptimalkan kegiatan pembelajaran dengan menggunakan lingkungan sebagai strategi pembelajaran, ada dua macam cara dalam menggunakan lingkungan, yaitu:

1. Membawa peserta didik dalam lingkungan dan masyarakat sebagai keperluan pelajaran (karyawisata).

2. Membawa sumber-sumber dari masyarakat ke dalam kelas pengajaran untuk kepentingan pelajaran (benda-benda, pameran, koleksi dll).

Usaha-usaha lain yang dapat digunakan dalam melaksanakan strategi lingkungan dalam pembelajaran di antaranya adalah:

1. Memberi pengetahuan tentang lingkungan kepada peserta didik.

2. Mengusakan agar alat yang digunakan berasal dari lingkungan yang dikumpulkan baik oleh guru maupun peserta didik.

3. Memberikan kesempatan kepada peserta didik untuk melaksanakan penyelidikan sesuai dengan kemampuannya melalui bacaan-bacaan

23 Wina Sanjaya, Strategi Pembelajaran Berorientasi Standar Proses Pendidikan, (Jakarta: Kencana Prenada Media, 2011), h. 100. 
dan observasi, kemudian mengekpresikan hasil penemuannya dalam bentuk percakapan, karangan, gambar, pameran, perayaan dan lain sebagainya. ${ }^{24}$

Apa bila seorang guru bermaksud mengajarkan konsep-konsep dalam suatu pokok bahasan atau topik tertentu dengan menggunakan lingkungan sebagai strategi dalam pembelajaran maka perlu dahulu mencari informasi tentang keterlibatan konsep yang diajarkan dengan peristiwa atau kejadian dalam lingkunggan. Sebagai contoh seorang guru ingin mengajarkan kepada siswa tentang jual beli, maka guru dapat mengajak para siswa kepasar, peran serangga dalam penyerbukan buah maka para siswa diajak ketaman, dll.

Melalui pendekatan lingkungan ini siswa diajak memahami konsep sain dengan menggunakan lingkungan sebagai sumber belajar. Dengan demikian mereka diharapkan akan memilki kepedulian terhadap lingkungannya dan berawal dari pemahaman dan kepedulian itu mereka dapat mencari solusi, mengambil keputusan dan melakukan tindakan nyata apa bila mereka suatu ketika menghadapi masalah dalam lingkungan mereka sendiri.

Untuk tercapainya proses dalam pembelajaran yang aktif, terpadu, dan memiliki karakter maka lingkungan tidak dapat terpisahkan dari proses pembelajaran. Karena hakikatnya adalah pembelajaran suatu interaksi antara individu dan lingkungan. Lingkungan menyediakan rangsangan (stimulus) terhadap individu dan sebaliknya individu memberikan respon terhadap lingkungan. Dalam

${ }^{24}$ Ahmad Rohani. Pengelolaan Pengajaran, (Jakarta: Rineka Cipta, 2004), h. 20. 


\section{Irjus Indrawan}

proses interaksi itu dapat terjadi perubahan pada diri individu berupa perubahan tingkah laku dan dapat juga terjadi individu yang menyebabkan terjadinya perubahan pada lingkungan, baik perubahan yang positif maupun yang negatif. Lingkungan yaitu situasi sekitar dimana pesan disampaikan, lingkungan dapat berupa fisik (gedung sekolah, kampus, perpustakaan, lab, stodio, museum, taman dll) maupun lingkungan non fisik (suasana belajar dan lain, lain). ${ }^{25}$

Hal ini menunjukkan bahwa fungsi lingkungan merupakan faktor yang penting dalam proses pembelajaran terutama dalam pendidikan agama Islam karena tujuan dari pendidikan agama Islam itu sendiri mengginginkan para peserta didiknya menjadi insan kamil, ini mengandung arti bahwa pendidikan agama Islam itu diharapkan menghasilkan manusia yang berguna bagi dirinya sendiri, masyarakat, gemar mengamalkan dan mengembangkan ajaran Islam dalam hubungannya dengan Allah dan dengan manusia sesamanya, dapat mengambil manfaat yang semakin meningkatkan dari alam semesta ini untuk kepentingan hidup dunia dan akherat .

\section{Kesimpulan}

Dalam Proses Pembelajaran, media telah dikenal sebagai alat bantu mengajar yang seharusnya dimanfaatkan oleh pengajar, namun kerap kali terabaikan. Tidak dimanfaatkannya media dalam proses pembelajaran pada umumnya dikarenakan oleh berbagai alasan seperti waktu persiapan mengajar terbatas, sulit mencari media yang tepat,

${ }^{25}$ Ahmad Rohani, Media Instruksional Edukatif, (Jakarta: Rineka Cipta, 1997), h. 108-109. 
biaya tidak mencukupi ataupun alasan yang lain Strategi pembelajaran dengan menggunakan lingkungan dalam proses pembelajaran, siswa tidak hanya untuk diajak mempelajari konsep tentang lingkungan tetapi lingkungan juga dapat menjadi salah satu sumber belajar.

Strategi pembelajaran menggunakan media lingkungan adalah segala sesuatu yang ada di luar dari diri individu. Adapun lingkungan dalam proses pengajaran merupakan segala apasaja yang bisa mendukung pengajaran itu sendiri yang dapat difungsikan sebagai sumber pengajaran atau sumber belajar. Strategi lingkungan ini, bukan hanya guru dan buku pelajaran saja yang menjadi sumber belajar tetapi banyak hal yang dapat dipelajari dan dijadikan sumber belajar peserta didik.

Lingkungan merupakan sumber peran yang sangat kaya sesuai dengan tuntutan kurikulum. Ada dua bentuk lingkungan belajar, pertama lingkungan yang sengaja didesain untuk belajar siswa seperti laborlatorium, perpustakaan, ruang internet dan lain sebagainya, kedua, lingkungan yang tidak didesain untuk proses pembelajaran akan tetapi keberadaannya dapat dimanfaatkan seperti halaman sekolah, kantin, masjid, hutan dan lain sebagainya. Pengajaran yang tidak menghiraukan lingkungan akan mengakibatkan peserta didik tidak mampu beradaptasi dengan kehidupan tempat peserta didik itu hidup. 


\section{Irjus Indrawan}

\section{DAFTAR KEPUSTAKAAN}

Arifin, M. 1991. Kapita Selekta Pendidikan. Jakarta: Bumi Aksara.

Budimansyah, Dasim. 2003. Model Pembelajaran PAI Berbasis Portifolio. Bandung: PT. Ganesindo.

D. Marimba. Pengantar Filsafat Pendidikan Islam. Bandung: PT. AlMa'arif.

Depdiknas. 1990. Manajemen Peningkatan Mutu Berbasis Sekolah. Jakarta: Dirjen Dikdasmen.

Dinata, Nana Syaodhisukma. 2002. Pengembangan Kurikulum Teori dan Praktek, Bandung: Remaja Rosda Karya.

Dradjat, Zakiyah. t.t., Ilmu Pendikan Islam: Bumi Aksara. Jakarta.

Effendi, Empy., Hartono Zhuang. 2005. E-Learning, Konsep dan Aplikasi. Yogyakarta: Andi.

Hamzah B. Uno., Nurdin Mohamad. 2011. Belajar Dengan Pendekatan Pembelajaran Aktif, Inovatif, Lingkungan, Kreatif, Efektif, Mandiri (PAILKEM). Jakarta: Bumi Aksara.

Hasbullah. 2005. Dasar-Dasar Ilmu Pendidikan, Jakarta: Raja Wali Press.

Isjoni. t.t. Pengembangan Profesional Guru, Pekanbaru: Cendikia Insani.

Iskandar, Sindi M., dan Hidayat, Eeddy M. 1997. Pendidikan Ilmu Pengetahuan Alam. Jakarta: Depdikbud Dikti. Prabawa, Andi Haris. 2002. Paragdima Pengembangan Kurikulum Pendidikan Tinggi, Surakarta: Universitas Muhammadiyah.

Rohani, Ahmad. 1997. Media Instruksional Edukatif. Jakarta: Rineka cipta. 
2004. Pengelolaan Pengajaran. Jakarta: Rineka Cipta.

Rugaiyah, Atiek Sismiati. 2011. Profesi Kependidikan. Bogor: Ghalia Indonesia.

Sanjaya, Wina. 2011. Perencanaan dan Desain Sistem Pembelajaran. Jakrta: Kencana Prenada Media Group.

Slameto. 2003. Belajar dan Faktor-Faktor Yang Mempengaruhinya, Jakarta: Rineka Cipta.

Sudirman. 1991. Ilmu Pendidikan, Bandung: Rosda Karya. Bandung.

Uno. Hamzah B. Uno. 2008. Profesi Kependidikan. Jakarta: Bumi Aksara.

Usman, Moh. User. 1995. Menjadi Guru Profesional. Remaja, Bandung: Rosda Karya.

Winaputra, Udin. 1997. Strategi Belajar Mengajar, Jakarta: Universitas Terbuka.

Wina Sanjaya. 2011. Strategi Pembelajaran Berorientasi Standar Proses Pendidikan, Jakarta: Kencana Prenada Media. 